\title{
A link between renewable energy, globalisation and carbon emission? Evidence from a disaggregate analysis with policy insights
}

Mohd Arshad Ansari ( $\sim$ 16seph17@uohyd.ac.in )

University of Hyderabad https://orcid.org/0000-0002-0889-8666

Vaseem Akram

Indian Institute of Management Jammu

Salman Haider

University of Hyderabad

\section{Research Article}

Keywords: CO2 emissions, Renewable energy, Fossil fuels, Globalisation, Pooled Mean group, Dumiterescu-Hurlin causality test

Posted Date: June 22nd, 2021

DOl: https://doi.org/10.21203/rs.3.rs-598651/v1

License: (c) (1) This work is licensed under a Creative Commons Attribution 4.0 International License. Read Full License 


\title{
A link between renewable energy, globalisation and carbon emission? Evidence from a disaggregate
} analysis with policy insights

Mohd Arshad Ansari ${ }^{\mathrm{a} *}$, Vaseem Akram ${ }^{\mathrm{b}}$, and Salman Haider ${ }^{\mathrm{c}}$

\begin{abstract}
This study unveils the question of how renewable energy, non-renewable energy, globalisation, and total factor productivity affect the carbon dioxide $\left(\mathrm{CO}_{2}\right)$ at the aggregate and disaggregate levels $\left(\mathrm{CO}_{2}\right.$ from oil, coal and gas) in 8 case of top ten carbon emitters developing economies over the period 1991-2016. To achieve the above objective, we 9 apply various panel unit, cointegration and causality tests. We also implement a Pooled Mean Group estimator technique to find the long-term coefficients. Findings from panel cointegration tests show that there exists a significant long-run relationship between renewable energy, non-renewable energy, globalisation, total factor productivity and

$12 \mathrm{CO}_{2}$. Moreover, findings derived from PMG infers that renewable energy consumption has a negative and significant 13 impact on $\mathrm{CO}_{2}$ while non-renewable energy consumption significantly increases the $\mathrm{CO}_{2}$ at aggregate and 14 disaggregate level. Further, our results show that total factor productivity increases the $\mathrm{CO}_{2}$ emissions whereas globalisation decreases it. From the policy point of view, our findings recommend that $\mathrm{CO}_{2}$ in sample countries can be reduced through promoting low carbon technology, and globalisation. Moreover, our findings propose to encourage renewable energy installation and drafting comprehensive policies.
\end{abstract}

Keywords: $\mathrm{CO}_{2}$ emissions; Renewable energy; Fossil fuels; Globalisation; Pooled Mean group; Dumiterescu-Hurlin causality test

JEL Classification: Q2 Q3 F6 O4

${ }^{a}$ University of Hyderabad, Hyderabad-500046, India, *Corresponding Author Email: 16seph17@uohyd.ac.in

${ }^{b}$ Economics \& Business Environment Area, Indian Institute of Management Jammu, Old University Campus, Canal 


\section{Introduction}

The growth of the economy and the progress of industrialisation are resulting in massive amounts of fossil-fuel energy usage. In recent years, globalised economies' economic and non-economic activities are based mainly on energy inputs that simultaneously lead to energy security and sustainable development (IEA, 2017; BP Global, 2018). As a result, it generates a large chunk of the Green House Gases (GHGs) emission. According to the BP Global (2018) forecast, a surge in global energy demand (GED) has been noted in the coming years. Further, it is mentioned that GED will continue to increase by triple times by 2040 under the Evolving Transition scenario ${ }^{1}$. This infers that GED will lessen the growth pace as compared to the last 25 years which thereby decay the level of energy-intensity (BP Global, 2018). This problem is more prominent in the fastest-growing economies like China and India and some other developing countries where the share of GED is two-third in economic growth (Global, 2018, BP). Moreover, over the decades, a structural shift in energy compositions such as fossil fuels (coal, oil, and natural gas) have been observed. From REN21 (2018), it has been noticed that fossil fuel is the key source of energy demand which found to be around 78 percent of GED whereas the share of consumption in renewable energy (REC) is noticed around 19 percent. Particularly, a significant shift from coal to gas is documented in upper-middle income economies (WEO, 2018). Further, followed by renewables and oil consumption, natural gas consumption is found to be the largest addition to the GED. According to the World Economic Outlook (WEO, 2018), natural gas usage could rise even more in the coming years, passing coal as the second most important source of primary energy by 2030. As a result, there would be a significant change in energy mix, investment, and technology, especially in emerging economies. Moreover, a continuous surge in GED-supply is sprouting in these countries to fulfill their needs. Given these facts, an enormous increase in GED certainly will boost the growth in GHGs emissions and it might be doubled by 2050 if serious attention is not paid to the reformulation of environmental policies (IEA, 2013).

While looking at the historical data, it has been observed that industrialized economies are accountable for a surge in global GHGs emission. However, in recent years, relatively high growth in GHGs is noted in emerging economies (IEA, 2017). In terms of GHGs, a vast disparity is seen across the globe. More specifically, around 80 percent to world $\mathrm{CO}_{2}$ is emitted by top 25 countries whereas the developing countries emit 60 percent and it further projected to increase by 80 percent to world $\mathrm{CO}_{2}$ (Huwart and Verdier, 2013). Most of the developing countries (or non-annex-I) are exempted to follow the Kyoto protocol. In other words, while the majority of developing nations are exempt from the Kyoto Protocol's commitment to reduce carbon emissions, these countries are expected to contribute to the fight against climate change and the reduction of greenhouse gas emissions. Developing countries are also making significant efforts to shift their energy-mix, create renewable energy systems, and promote energy-efficient technology. However, because energy efficient and pollution-controlling technologies are widely used in developed countries, there is a significant gap between developed and developing countries in terms of energy intensity and CO2GDP ratio (Ertugrul et al., 2016). In Figure 1, we display the energy intensity of our sample countries (top ten developing, and six developed countries). The U.S has relatively higher energy intensity, but as compared to other

\footnotetext{
${ }^{1}$ Assume that social preferences, technology, government policies continue to progress in away and speed seen over the past few years.
} 
developing and developed countries it has lower energy intensity ratio. There is also need to identify different sources of emission which vary across countries because the dynamic relationship with related impact factors also differs with respect to sources of emission (Ahmad et al., 2016; Nain et al., 2017).

\section{Insert Figure 1}

Insert Figure 2

In Figure 2, we plot the share of different fossil-fuel like coal, natural gas and oil to total carbon emission of top ten carbon emitters developing countries. From Figure 2, we visualize that there has been a substantial variation across these countries in terms of energy and emission sources. For example, China, India, and South Africa heavily rely on coal consumption, thereby having the largest share of $\mathrm{CO}_{2}$ emission.

Furthermore, renewable energy is a key component of handling the problem energy-security and reduction in GHGs emissions. In addition, "it tells about non-exhaustive source of energy that should be increased for long-term sustainability (Bhat, 2018)". According to existing studies, the government's initiative in recent years has resulted in a significant decrease in the cost of renewable energy technology, which has evolved in tandem with the increase in energy demand. Despite the fact that renewable energy has a low part of the energy mix in recent years, policymakers and researchers are nonetheless curious about the solution to the question of "how does renewable energy lead to economic growth and emissions?" (Shahbaz et al. 2015a,b; Apergis and Payne 2015; among others). Further, it is stated by the researchers that the world has accomplished one pace towards in the globalisation process with help of technological progress. Hence, it shows the connection between economic activity and GED across the world (Ansari et al. 2020c). Moreover, a study by Shahbaz et al. (2016a) gives the different flavours of how globalisation only affects GHGs emission. Globalisation, it is believed, boosts the diffusion of green and clean technologies with best practises (Huwart and Verdier, 2013). Since technological enhancement plays an essential in economic development and delivers an improved signal of the growth process over the time. Recently few studies also studied the role of total factor productivity (TFP) in influencing energy consumption and carbon emission reduction (Haider and Ganaie 2017; Ladu and Meleddu 2014). As it is a good proxy for technological progress, it shows the growth of output not attributed to the growth in inputs. Technological advancements have the potential to reduce the carbon emission level by improving the efficiency in energy use, pollution treatment etc. (Bhat, Haider, and Kamaiah 2018; Haider and Bhat 2018; Ansari et al. 2020a).

Despite the vital role of globalisation, TFP, renewable and non-renewable energy (NREC) demand and GHGs emission, studies on the link between environment and its influencing macroeconomic factors are scanty. Hence, "there is a need for close investigation of the relationship between environment and its influencing macroeconomic factors to design a nuanced energy and environmental policy". Further, given the position of globalisation and technological progress in the existing literature, the current study bridges this research gap by investigating the impact of globalisation, TFP, renewable and non-renewable on the different carbon emission sources (or disaggregate level). In the global level, we consider the sample of top ten emitting nations which is prime importance in international negotiation on climate change. To the best of authors' knowledge, none of the previous studies examined the impact of globalisation, TFP, renewable and non-renewable on carbon emission at the disaggregate level (emission from coal, gas and oil) in a panel data framework in the top ten carbon-emitting countries among developing nations. In one of Ertugrul et al., (2016) 
studies, he showed the impact of energy consumption on carbon emissions in top carbon emitters by taking aggregate

111 level into account. As a result, this study adds to the research on the carbon-influencing macroeconomic factors nexus in the following ways. To begin, this work differs from previous works in that it uses TFP as a proxy for economic growth to evaluate the role of total productivity in carbon emissions. Second, we explore long-run relationships and elasticities using the advanced panel data model, i.e., pooled mean group (PMG). Because most cross-country studies neglect the issue of cross-sectional dependency in the error term which lead to biased results. This problem is critical from the perspective of global economic coordination on "climate change and voluntary carbon emission reduction". Third, we have used a unique dataset of emission from coal, gas and oil-related to the top ten developing countries at disaggregated levels which have the largest potential for reduction in emissions. Finally, we developed a robust technique of long-term impact that incorporates both the cross and time dimensions of the data point, resulting in a considerable improvement in estimation over studies that exclusively use the time series method.

The remaining part is assembled as follows: literature review section supply assessment of relevant studies. The data and methodology part delineate the empirical modeling, data collection and methods of estimation. The empirical findings and discussion present results and discussion and the conclusion and policy implication division summarize article with the concluding remark and some relevant policy implications.

\section{Literature Review}

The theoretical foundation of the environmental Kuznets curve (EKC) has been empirically examined in a large number of studies. It has been tested by investigating the causal link between energy consumption and economic growth. This is the widely tested and debated hypothesis in literature related to environment/energy. However, there is no single consensus in validating the EKC hypothesis (Tiba and Omri 2017). The reason could be that the EKC hypothesis is vary with respect to determinants, time-duration, and techniques employed in the examination. Studies by Tiba and Omri (2017) and Ansari et al. (2020b) make available a wide-ranging literature survey on EKC hypothesis. Based on the literature survey, these studies recommend further investigation EKC hypothesis by augmenting the EKC model with other relevant variables. For more details, kindly refer the Tiba and Omri (2017). Given the role of renewable energy consumption in recent years of government mission to achieve the full potential production of renewable energy, the recent studies have distinctly studied the effect of renewable energy consumption along with non-renewable energy consumption on economic growth and $\mathrm{CO}_{2}$ emission.

A set of studies have inspected a causal link consumption of energy and $\mathrm{CO}_{2}$ emissions- in total at aggregated level empirically (Zhang and Cheng, 2009; Jalil and Mahmud, 2009; Kuo et al. 2014; Bautobba, 2014; Dietzenbacher and Mukhopadhyay, 2007; Ocal et al., 2013; Bhattacharyya and Gkoshal, 2010; Ang, 2008; Soytas and Sari, 2009 and China et al., 2014). The paper investigates the relationship between carbon emissions, renewable energy, non-renewable energy, total factor productivity, and globalisation that has diverse characteristics.

Furthermore, only a few researchers have looked into the impact of globalisation on CO2 emissions and energy consumption, and various proxies of globalisation have been used as indicators of globalization, i.e., trade openness. There are no clear-cut conclusions (or mixed ones) in terms of the dominance of size or the composition influence of trade, there are no clear-cut conclusions (or mixed ones) (Cole, 2006; Copeland, and Taylor, 2004; Antweiler et al., 2001; Ansari et al. 2020d). Some researchers looked at a causal association between usage of energy, economic progress, 
and trade, however the evidence was inconclusive (Hossain, 2012; Shahbaz et al., 2013a, 2013b; Shahbaz et al., 2014a; Nasreen and Anwer, 2014).

Existing studies have been divided into two portions to maintain the relevancy of the empirical investigations., (i) studies based on a link between $\mathrm{CO}_{2}$ emission and renewable energy consumption is are given in Table 1; (ii) literature on the relationship between globalisation, energy consumption and carbon emission (an indicator of environmental quality) are reported in Table 2. Table 1 shows that no single study has come to the conclusion that increasing renewable energy usage reduces CO2 emissions. On the Except for Sebri and Ben-Salha (2014) and Apergis and Payne (2014) the majority of literatures indicated that increasing renewable energy use reduced CO2 emissions (2014).

The studies which are examining the effect of globalisation on $\mathrm{CO}_{2}$ emissions have found mixed findings stating that globalisation enhances or reduces the $\mathrm{CO}_{2}$ emissions. The method used, distinct supplementary variables, time period, and sample size could all be factors in contradicting results (Dogan and Seker, 2016a). There is no clear findings in the existing study which suggest further investigation in a more coherent manner. There are limited studies that uses the as a globalisation index to measure the features of globalization, i.e., economic, social, and political. As a result, we have expanded the literature by conducting a thorough examination of the effects of globalisation and TFP on $\mathrm{CO} 2$ emissions at both the aggregate and disaggregate levels.

\section{Data and Methodology}

\subsection{Data consolidation and model}

The present section describes the sample countries that have been taken for the analysis, variable measurement and description. We have considered the top ten $\mathrm{CO}_{2}$ emitters among developing countries that are important for reducing $\mathrm{CO}_{2}$ at the global level. We have employed annual panel data spanning from 1991-2016 and estimated an augmented $\mathrm{CO}_{2}$ emission function. The developing countries chosen for the study are China, Malaysia, Turkey, South Africa, Indonesia, Mexico, Brazil, India, South Korea and Thailand. The study uses natural logarithms to obtain an efficient and consistent outcome which also overcomes the problem associated with heteroskedasticity and provide direct elasticities by converting them into log specification. Following earlier studies (Paramati et al. 2016; Alam et al. 2016; Ansari et al., 2019), we convert all the variables in the natural log-linear form to minimize the problem related with distributional properties of estimated coefficients. Table 3 shows the name of variables, their symbols, description, and the measurement of units as well as data source used in this study.

\section{[Insert Table 3]}

To empirically analyze the effect of renewable and non-renewable energy at aggregated and disaggregated levels on carbon emissions we employ the following algebraic form of equations

$$
L n C O_{2}=\beta_{0}+\beta_{1} \operatorname{LnNREC}+\beta_{2} \operatorname{LnREC}+\beta_{3} \operatorname{LnTFP}+\beta_{4} L n G+\mu
$$

Where $\mathrm{LnCO}_{2}$ represents the natural log of per capita carbon emissions; LnNREC is the natural log of per capita nonrenewable energy consumption; LnREC denotes the natural log of per capita renewable energy consumption; TFP is the 
natural $\log$ total factor productivity and $\mathrm{LnG}$ is the natural $\log$ of per capita globalisation. In addition, $\beta_{0}$ is constant and $\mu_{\mathrm{t}}$ is the unknown error term. A separate function for the consumption of non-renewable energy (coal, oil and gas) at disaggregates analysis is depicted by the following equations.

$$
\begin{aligned}
& \text { LnCO } O_{2} \text { Coal }=\beta_{0}+\beta_{1} \text { LnECcoal }+\beta_{2} \text { LnREC }+\beta_{3} \text { LnTFP }+\beta_{4} \text { LnG }+\mu \\
& \text { LnCO }_{2} \text { Oil }=\beta_{0}+\beta_{1} \text { LnECoil }+\beta_{2} \text { LnREC }+\beta_{3} \text { LnTFP }+\beta_{4} L n G+\mu \\
& \text { LnCO }_{2} \text { Gas }=\beta_{0}+\beta_{1} \text { LnECgas }+\beta_{2} \text { LnREC }+\beta_{3} \text { LnTFP }+\beta_{4} L n G+\mu
\end{aligned}
$$

Eq. (2-4) is used to analyze the effect of non-renewable energy consumption, REC, TFP and globalisation on carbon emissions.

\subsection{Cross-sectional dependence and heterogeneity}

Before employing a panel data estimation technique, one should be aware of cross-sectional dependence in the error term (Pesaran, 2004). This study uses cross-sectional dependence test employing four different statistics tests to investigate whether each panel (time series) has cross-sectional independence.

For this purpose, the study applies Pesaran (2004)'s cross sectional (CD) ${ }^{2}$, Breusch and Pagan (1980)'s Lagrange multiplier approach (LM), Pesaran scaled LM and Bias-corrected scaled LM test. Referring to Table 4 the null hypothesis of cross-sectional independence of all the variables of the interest can be rejected at 1 per cent level of significance. Hence, we can proceed for unit root test because the variables under investigation have panel heterogeneous cross-sectional dependence.

\subsection{Panel unit root tests}

In analyzing the stationary properties of the variables, we have used four different unit root tests. Levin Lin Chu by Lin and Chu (2002), Augmented Dicky-Fuller (ADF) by Dicky and Fuller (1984), Philiips-Perron (PP) by Phillips and Perron (1988) and Im, Pesaran and Shin (IPS) by Im et al. (2003) to test whether the variables contain unit root problem or not. As mentioned previously, these unit root tests produce an accurate outcome by using dynamic autoregressive coefficient, which allows for heterogeneity across the sample countries and identify the order of integration of variables very suitably. The order of integration either $\mathrm{I}(0)$ or $\mathrm{I}(1)$, is found through testing variables at levels and if it is not stationary then we will proceed to apply unit root test at their first differences, this indicates that all the variables are non-stationary at the level and stationary at first difference. This allows us to proceed to test for the existence of a longrun relationship (cointegration) among variables for the model (1-4).

214

\subsection{Panel cointegration test}

We employ Pedroni's $(1999,2004)$ cointegration techniques to check the long-run equilibrium relationship among the variables used in the model (1-4). Pedroni cointegration test yields consistent estimate of the test statistic in the presence of cross-section dependence and relatively small sample size hence it is widely applied in the panel cointegration analysis

\footnotetext{
${ }^{2}$ This test is used in both case balance and unbalance panels data where $\mathrm{T}<\mathrm{N}$

${ }^{3}$ The test performs well while working with panel countries with $\mathrm{T}>\mathrm{N}$.
} 
(Bhat, 2018). Since Pedroni cointegration test ${ }^{4}$ is based on heterogeneous panels, it has seven test statistics based on two sets of cointegration analysis and allows for cross-section interdependence with various effects on the individual parameter. The first four sets of panels cointegration test known as within dimension ${ }^{5}$ include v-statistic, PP- statistic, rho-statistic and ADF-statistic. The second set comprises three group statistics known as between-dimension ${ }^{6}$ includes rho-statistic, ADF-statistic and PP-statistic. Null of no cointegration is tested against the alternate hypothesis that there is cointegration among the variables. We have also used Kao panel cointegration test developed by (Kao C, 1999; 1990). On the first stage of regressors, these Kao panel cointegration techniques include homogeneous coefficients across all units which follow a similar procedure as Pedroni cointegration techniques.

\subsection{Long-run estimates}

After we confirm the level of emissions, total factor productivity, globalisation, renewable energy and non-renewable energy consumption has a long-run association. One can employ Pooled mean group estimator (PMG) proposed by Pesaran and Smith (1995) and Pesaran et al. (1999). The majority of empirical studies have used ordinary least square (OLS), fully modified ordinary least square (FMOLS) and Dynamic (OLS) techniques. The mentioned techniques are based on the assumption of independent cross-sections, however, they may fail to show the accurate and efficient outcome. For this purpose we also investigate issue of cross sectional dependence and heterogeneity for these models. Pooled mean group (PMG) is basically an extension of the time series ARDL approach. Pirotte (1999) found that PMG estimator gives an efficient parameter and considered to be freely independent across groups for the large sample size and does not allow possible homogeneity among groups. There are several merits of PMG, for instance, whether variables are I(0) or I(1), detected inferences can be made by using PMG estimator. PMG allows for error variance, intercept and short-run slope to vary across units. Moreover, long-run coefficients can be interpreted as elasticities if variables are in log-linear form. The following error correction specification of PMG is used to derive short-run as well as long-run estimates of coefficients.

$$
\Delta z_{2 t}=\gamma_{i}\left(z_{i, t-1}-\delta_{i}^{\circ} y_{i, t-1}\right)+\sum_{k=1}^{n-1} \beta_{i k}^{*} \Delta z_{i, t-1}+\sum_{k=1}^{o-1} \pi_{i k}^{\circ *} \Delta y_{i, t-k}+\rho_{i}+\infty_{i t}
$$

Where $\mathrm{z}$ denotes the dependent variables (emissions; total, from coal, oil and gas), $\gamma_{i}$ represents the error correction

coefficient which shows the speed of the adjustment process. $\left(z_{(i, t-1)}-\delta_{i}^{\circ} y_{i, t-1}\right)$ show significance of divergence from the long run relationship for any unit i.e. $i=1,2,3 \ldots \mathrm{N}$ and at any time interval $\mathrm{t}=1,2,3 \ldots \mathrm{T}$. If $\gamma_{i}$ is found to be 0 then there is confirmation of no cointegration. The term $\delta_{i}^{\circ}$ shows that similar variables form a long run coefficient of respective dependent variables indicated by $y_{i, t-1}$, the $\pi^{\prime} s$ potrays the short run coefficients. The vector $\rho_{i}$ is time

\footnotetext{
${ }^{4}$ It is residual based test therefore estimated residual are defined as $\varepsilon_{i t}^{\tilde{*}}=\rho_{i} \tilde{\varepsilon_{i t-1}}+\omega_{i t}$

${ }^{5}$ Common autoregressive coefficients across nations are taken into account in these test statistics

${ }^{6}$ For each country in the panel, these statistics are based on the individual autoregressive coefficients and are categorised on the between dimension
} 
invariant country specific effect which is unobserved in the model and finally specific error value is observed indicated by vector $\infty_{i t}$ in the equation 5 .

\section{Results and discussion}

\subsection{Order of integration of the variables} Initially, applying the suitable form of unit root tests LCC, IPS, ADF and PP as discussed earlier, we have checked the stationary properties of all the variables. Before conducting unit root test, we have examined cross sectional dependence (CSD) of all the variables in panel which exhibits cross-sectional dependence. The test statistics for unit root analysis are displayed in Table 5. The findings supported the hypothesis of non-stationary at aggregate and disaggregate levels for carbon emissions, CO2 emissions from coal and oil, NREC from coal, total NREC, REC, and total factor productivity. However, after applying to their first difference to the series, all the variables become stationary at I(1) in nature, showing the same order of integration, thus strongly rejecting the null hypothesis at 1, 5 and 10 percent level of significance. Moreover, the variables like $\mathrm{CO}_{2}$ emissions from gas, non-renewable energy consumption from oil and gas, globalisation at disaggregate levels show the rejection of null hypothesis (non-stationary) at levels $\mathrm{I}(0)$ as well as their first difference I(1) at 1 and 5 percent level of significance. This allows us to proceed for cointegration analysis that there may be a long-run relationship between the analyzed variables.

\section{[Insert Table 5]}

\subsection{Analysis of long-run equilibrium relationship}

Unit root tests in the above section confirming the same level of integration for all the variables enable us to apply panel cointegration techniques to examine the long-run relationship among the variables. The results of the long-run equilibrium test are reported in Table 6 . The results contain seven tests, four tests are within dimension and other three tests are between dimensions as we have mentioned before. It is clear from the Table 6 that out of seven tests statistics the evidence of long-run equilibrium relationship (in all four model) are found in four tests, rejecting the null hypothesis of no cointegration at 1,5 and 10 per cent level of significance, hence confirming presence of cointegration among carbon emissions, renewable energy, non-renewable energy, total factor productivity and globalisation both at aggregated and disaggregated levels in a panel of top ten carbon emitters in developing economies. Similarly, Kao (1999) test shown in lower panel of Table 7 again validates the existence of a significant long-run equilibrium relationship among all the variables at aggregated and disaggregated levels at 1 and 5 percent significance level. Thus, it implies that these variables have long-run relationship among variables in the long run.

\subsection{The long-run elasticities:}

4.3.1 Aggregated emission

277 We have estimated the long and short run impacts of NREC, REC total factor productivity, and globalisation on $\mathrm{CO}_{2}$ 278 emission at the aggregated and disaggregated levels. For this, we employed PMG method introduced by Pesaran et al. (1999) and Pesaran and Smith (1995) to explore the long term impact and short-term dynamics. The results of these models are showed in Table 8. The coefficient of model 1 shows that increase in the NREC stimulates the level of carbon emissions. In other words, a $1 \%$ rise in NREC boosts $\mathrm{CO}_{2}$ emissions by $0.65 \%$ in the top emissions economies. More 
precisely, the consumption of energy estimate, in the analysed countries ranges from $0.65 \%$ to $0.96 \%$, as expected; the usage of energy increases the level of pollution of the examined countries. This empirical finding is in line with Ansari et al., (2019), Farhani et al., (2014) and Kasman and Duman (2015). Because consumption of energy is a vital and significant source in manufacturing activity, governments cannot afford to stop using it. Since then, energy use has been identified as one of the major contributors to environmental degradation. These nations should find a different source of energy to reduce their environmental impact. One of the possible methods for reducing carbon emissions is to improve energy efficiency. Low energy efficiency, according to Wang et al. (2015), increases emisisons from CO2 in China. Simultaneously, increasing the percentage share of consumption of renewable energy (environmentally friendly) in overall energy consumption is another possible measure that will reduce carbon emissions in these top CO2 emitting countries (Dogan and Seker, 2016a; Shafiei and Salim, 2014).

The empirical results in Table 7 also imply that increase in the consumption of renewable source of energy mitigates $\mathrm{CO}_{2}$ emissions in the top carbon emitter's countries. One per cent increase in the REC reduces the level of carbon pollution by $0.79 \%$. Hence, it suggests that NREC and REC contribute positively and negatively to $\mathrm{CO}_{2}$ emissions. Moreover, the consumption of renewable source of energy improves the environmental quality. Therefore, formative assessment to overcome the challenges associated with environmental pollution is the advancement of renewable energy usage and improvement in energy efficiency which helps in low carbon emissions (Ansari et al. 2020e).

Although REC helps in mitigating environmental degradation in top carbon emitting economies still much more needed for the renewable energy source to meet both the Paris agreement and the sustainable development goals to increase the percent share of clean source of energy in these nations, this can be accomplished by: (i) increasing energy independence and security, (ii) reducing environmental pollution and providing access to modern energy, (iii) reducing energy demand in all sectors by 2030, (iv) reducing non-renewable energy consumption, particularly oil and coal, while increasing the use of renewable energy sources. (v) adequate financial instruments, such as incentives, subsidies, and the removal of barriers, are required to accelerate investment in the renewable energy sector. Finally, in order to meet the Paris Agreement's goals, the elimination of subsidies and the implementation of a carbon price scheme are critical. Feed-in tariffs have previously proven to be effective in encouraging the growth of renewable energy (REN21, 2018). This result is crucial for designing climate change policy and further verified with the disaggregate dataset that whether different sources of carbon emission are equally affected by REC? Furthermore, the elasticities of carbon emissions with respect to TFP and globalisation are 0.53 and -0.13 , respectively. This finding implies that the rise in TFP level increases 312 but statistically insignificant. The increasing relationship between TFP and carbon emissions is consistent with studies 313 including Salma and Ganaie (2017); Ladu and Meleddu 2014. Hence, this reveals that higher levels of technology lead 314 to economic growth and hence demand more energy, which generates carbon emissions. Therefore production efficiency 315 reduces energy requirement which in-turn induces energy consumption and carbon emissions. This phenomenon shows 316 the presence of rebound effects. Globalisation at the aggregate level does not have a significant impact, further explored 317 by disaggregating data. This relationship is opposite to the study suggested by Sabir and Gorus (2019) which showed the positive impact of globalisation on environmental pollution in South Asian countries. 


\subsubsection{Emission from Coal}

The relationship between non-renewable energy (coal consumption) and $\mathrm{CO}_{2}$ emissions from coal is found to be statistically significant and positive. A $1 \%$ increase in coal consumption increases carbon emissions from coal by $0.90 \%$. These findings are consistent with Shahbaz et al., 2015c; Tiwari et al., 2013; Ashfaq et al., 2016) in India at disaggregate analysis. They found that increase in coal consumption increased leads to environmental degradation. The impact of economic growth and coal consumption on $\mathrm{CO}_{2}$ emissions referring to Chandran Govindran and Tang (2013) concluded that no long run association between the analysed variables exists. This study was different from ours; they utilized overall $\mathrm{CO}_{2}$ emissions together with economic growth and coal consumption whereas in our study we used carbon dioxide emissions from coal, oil and gas separately. Furthermore, the empirical results also show that REC lessens the level of emissions generated from coal consumption, meaning thereby $1 \%$ increase in REC helps reduce carbon emissions generated from coal by $-1.26 \%$. Regarding the impact of total factor productivity and globalisation, it is observed that TFP results to be statistically insignificant but has positive effects on $\mathrm{CO}_{2}$ emissions whereas $\mathrm{G}$ is found to be statistically significant and has a negative effect on carbon emissions. This finding is in conformity with many recent studies like Shahbaz et al. (2017a), Shahbaz et al. (2018b) showing increase in globalisation reduces $\mathrm{CO}_{2}$ emissions. On the contrary, more recent studies like Shahbaz et al. (2018c) showed that globalisation increases carbon emissions in 25 developing countries. The importance of globalisation is revealed here in reducing carbon emission from coal consumption hence policy should be designed for opening of the economy as per the developing countries is concerned. Most developing countries have the largest share of coal in the total energy mix, which is also emissionintensive. Therefore, policy for increasing the level of globalisation should be given due importance. Further the results are different from that of aggregate analysis and hence this shows aggregation bias may be problematic and need indepth analysis.

\subsubsection{Emission from Oil and Gas}

Similarly, Model $3 \& 4$ of Table 8 provides the long-run coefficient of the relationship between $\mathrm{CO}_{2}$ emissions from oil and gas consumption and its influencing variables. It is observed that the oil and gas consumption has a positive and statistically significant impact on carbon emission from oil and gas consumption. In other words, $1 \%$ increases in oil and gas consumption increase carbon emissions by $0.96 \%$ and $0.84 \%$ generated from oil and gas consumption respectively. Some studies examined the emission-energy-growth nexus at disaggregate studies for India and found that there is no cointegration among the variables (Ashfaq et al., 2016; and Chandran and Tang., 2013). Some studies Muhammad (2013), Ashfaq et al. (2016) and Khalid. (2013) also examined the nexus at aggregate and disaggregate levels. Their results were similar to our study, they found that coal, oil and gas consumption simulate $\mathrm{CO}_{2}$ emissions while gas consumption is less polluting than other energy resource representing environment-friendly. Our results show that the coefficient of REC is again negative and statistically significant as in the case of coal consumption model. A $1 \%$ increase in REC reduces $\mathrm{CO}_{2}$ emissions from oil and gas by $-0.19 \%$ and $-0.24 \%$ respectively. Finally, TFP stimulates carbon emissions whereas globalisation mitigates carbon emissions from oil and gas in the top ten developing countries. This shows that the robustness of our results that TFP has rebound effects on $\mathrm{CO}_{2}$ emissions. As pointed out above, among all energy sources, a disaggregated analysis assists in finding the minimum carbon polluting energy source for the country's economic growth. In our case, the empirical outcome shows that gas consumption is least polluting energy 
source with all other NREC (suc as coal and oil). For stable economic development in the top carbon emitter's among developing nations, it is required to use better technology for sustainable economic development and environmental quality.

[Insert Table 7]

\subsubsection{Short-run Dynamics}

The short-run results are shown in the lower part of Table 7. As can be seen, the effect of non-renewable, total factor productivity, and globalisation are statistically insignificant at the aggregated and disaggregated levels. However, the effect of renewable energy source is found to be significant but positive on carbon emissions in the (Model 2) of shortrun analysis ${ }^{7}$. The error correction explains the adjustment speed towards a long-run path from short-run disequilibrium at the aggregated and disaggregated level. It can be observed that ECTt ${ }_{-1}$ is statistically significant and negative at $5 \%$ significance level, describing the long-run relationship between emissions and NREC, REC, TFP and G at the aggregate level validating short-run deviation in $\mathrm{CO}_{2}$ emissions way forward to long-run equilibrium path by $-0.33 \%$ per year. In addition, the error correction coefficients for disaggregate analysis coal, oil and gas are also negative and significant statistically at $1 \%$ significance level reported the speed of adjustment in $\mathrm{CO}_{2}$ emissions are $-0.34,-0.89$ and -0.59 respectively. Furthermore, it can be analysed that speed of adjustment from short-run towards a long-run path (Model

372 3) for oil is faster than other energy (Models), whereas for the aggregate level speed of adjustment is lower than

373 disaggregate levels. Thus, aggregate non-renewable source energy is less polluting than another source of energy in top ten $\mathrm{CO}_{2}$ emitters in developing countries. On the contrary, oil consumption is a top contributor to carbon emissions in developing countries. In recent years, there is greater importance of REC as one of crucial solution for reducing GHG emission. The recent empirical studies try to establish the linkage between carbon emission and REC and estimated using time-series and panel-data technique. This study enhances the understanding of this regard which shows the unambiguous role of REC in reducing carbon emission. Further, the results identified the use of disaggregate dataset to reveal the influence of globalisation on different carbon emission sources. Hence, globalisation should be promoted across developing countries to reduce carbon emission from different sources of fossil-fuel energy consumption.

\section{Dumitrescu-Hurlin panel causality test}

In order to perform the panel causality among $\mathrm{CO}_{2}$ emissions, renewable energy, non-renewable energy, total factor productivity and globalisation in the top ten carbon emitters among the developing countries at the aggregate and disaggregate levels, the Dumitrescu and Hurlin (2012) test is applied. This technique is considered to allow coefficient to vary across cross sections and consider heterogeneity and cross-sectional dependence. We have used the first difference series because the examined variables in the model should be stationary to run this test. Table 8 summarizes the results of panel causality test. The empirical evidence show that the unidirectional granger causality is running from LnNREC and LnREC to $\mathrm{LnCO}_{2}$ (model 1) while unidirectional granger causality is found from LnNREC coal and LnREC to $\mathrm{LnCO}_{2}$ coal. However, the causality between LnTFP, and $\mathrm{LnCO}_{2}$ and $\mathrm{LnCO}_{2}$ coal is found to be bidirectional, this indicate that total factor productivity causes total carbon emissions as well as carbon emissions generated from coal

\footnotetext{
7 This may be due to beginning of replacement of non-renewable source energy by renewable and environment friendly energy.
} 
in the top carbon emitter's countries (model 2). Moreover, the consumption of oil also causes $\mathrm{LnCO}_{2}$ emissions from oil consumption. Hence, we can conclude that energy consumption at aggregated and disaggregated levels causes environmental pollution, whereas Globalisation mitigates while total factor productivity stimulates carbon emissions in developing countries.

\section{[Insert Table 8]}

\section{Conclusions and policy implications}

While the bulk of the studies analzyed the role of economic growth, trade openness, financial and development on $\mathrm{CO}_{2}$, studies on the link between renewable and non-renewable energy consumption, total factor productivity and globalisation and $\mathrm{CO}_{2}$ at aggregate and disaggregated level are scanty. By using the top ten emitter countries data for the period 1991-2016, this study adds to the existing literature with new policy insights by investigating the linkage between REC, NREC, total factor productivity, globalisation and $\mathrm{CO}_{2}$ and $\mathrm{CO}_{2}$ from coal, oil and gas. To do so, we first implemented the array of panel unit root test to check the stationarity of the variables. Second, we panel applied several panel cointegration test to find the long-run relationships among the variables. Third, once, we established the long-run relationships among the variable, we identified the short and long-run relationship between renewable energy consumption, non-renewable energy consumption, total factor productivity, globalisation and $\mathrm{CO}_{2}$ by using the PMG test. Fourth, we used the Dumitrescu-Hurlin panel causality test to check the causation between the variables.

Empirical findings from the panel unit root tests showed that all variables contain the unit root. Outcome derived from panel cointegration tests exhibited the existence of the long-run relationship between $\mathrm{CO}_{2}$ and renewable energy, non-renewable energy, globalisation, and total factor productivity. Further, findings obtained from PMG concluded that renewable energy consumption has a negative and significant impact on $\mathrm{CO}_{2}$ while non-renewable energy consumption significantly increases the $\mathrm{CO}_{2}$ at aggregate and disaggregate level. Our findings also showed that total factor productivity positively linked to $\mathrm{CO}_{2}$ emissions whereas globalisation decreases $\mathrm{CO}_{2}$.

These findings have important implications in many folds: First, to improve the environmental quality without compromising the country's economic development, policymakers should focus on the disaggregated energy resources that help identify the substitute for coal consumption, which can furnish heat for industrial purposes. Based on our results, gas energy consumption is less polluting than other forms of the energy resource, which is beneficial in improving environmental damages. Second, our findings recommend that less dependency on non-renewable energy consumption can help in reducing $\mathrm{CO}_{2}$ emissions. This can be done by increasing renewable energy consumption. In particular, off-grid energy solutions allow developing nations to embrace electrification in rural areas and a low carbon pathway which can only be achieved by emphasizing more on renewable energy sources. For instance, China has been able to make into the sector of renewable energy where consumption of total energy in China is 93,800 petajoules, out of which 12,293 comes from a renewable source. This indicates that 12 percent of its consumption is fulfilled by renewable energy. The usage of renewable energy consumption in Indonesia, Turkey and Philippines has also gained the importance of using clean energy source for which their requirements are being fulfilled by renewable energy. Third, declining the usage of energy consumption is not easy particularly in developing nations, for which developing nations should support financially through decreased energy intensity, at the same time increasing the efficiency of energy usage 
in these countries. As Wang et al. (2015) argued, one possible reason for this increase in carbon emissions is the high energy intensity. Fourth, policies related to promoting globalisation should be encouraged particularly based on their needs to access energy-efficient technology from developed countries to developing countries. This can be done "when

431 a country actively participates in international negotiation on climate change and other energy-related international

432 organisations". Lastly, two different nature of energy has a different impact on carbon emission as it is expected. Given

433 the possibility of potential substitution between these two energy forms (renewable energy consumption and non-

434 renewable energy consumption), the climate change policy of developing countries should give more attention on

435 development and consumption of renewable energy consumption on a priority basis. They should encourage the use of

436 renewable energy sources of energy in the private sector through a market-based mechanism and carbon tax sort of

437 regulation to discourage widely used fossil-fuel sources of energy. Hence developing countries on the line with the

438 developed country should implement some of the policy options like REC production tax credits, installation rebates for

439 REC system, REC portfolio standards, and the implantation of markets for REC certificates to promote investment in

440 renewable energy consumption technologies.

441 Declaration

442 1. Ethics approval and consent to participate: Not applicable

443 2. Consent for publication: Not applicable

444 3. Availability of data and materials: Available upon request

445 4. Competing interests: The authors declare that they have no competing interests

446 5. Funding: Not applicable

447 6. Authors' contributions: Mohd Arshad Ansari conducted methodology, data and initial draft; Vaseem Akram

448 conducted literature review and final draft; Salman Haider prepares the final draft of the paper.

449

450 


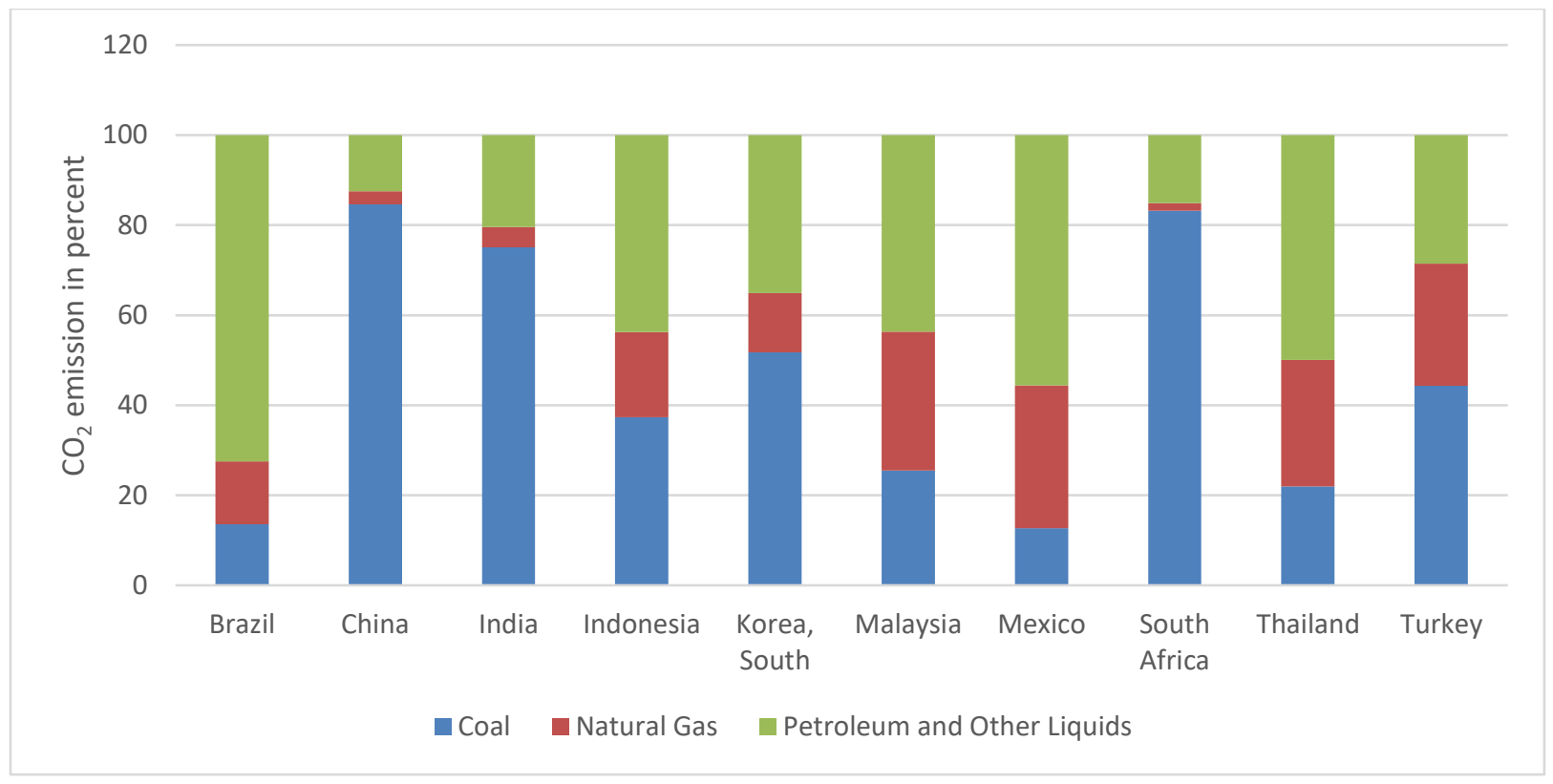

Figure 1. Sources of $\mathrm{CO}_{2}$ emission from different energy use

457

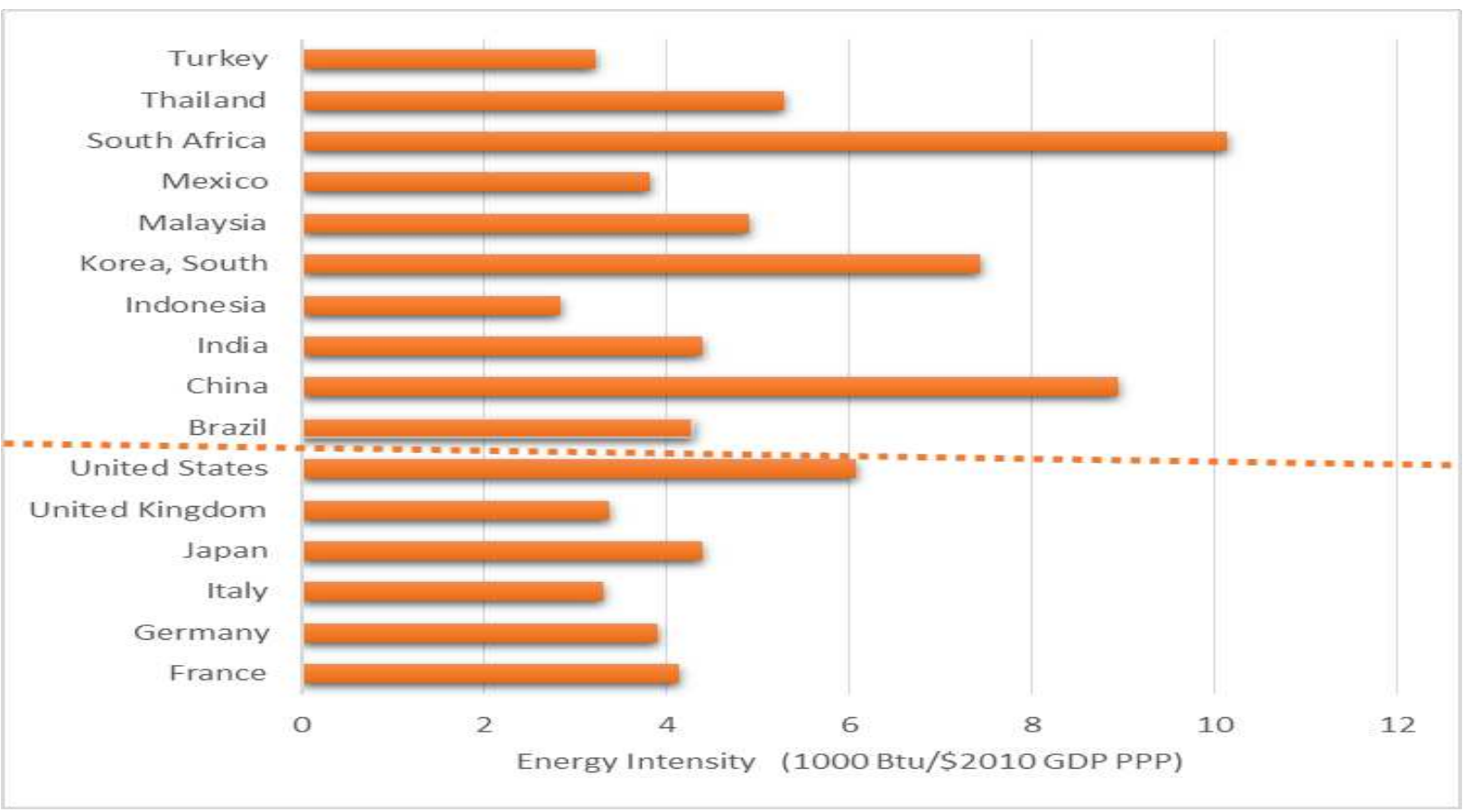

Figure 2. Energy intensity in developing and developed countries 
Table 1: Survey literature on the link between $\mathrm{CO}_{2}$ emissions and renewable energy consumption

\begin{tabular}{|c|c|c|c|c|}
\hline Author & Sample-Year & Sample-countries & Methdology & Findings \\
\hline Sadorsky (2009) & 1980 to 2005 & G7 & PC, ECM & $\begin{array}{l}\text { Positive impact of } \mathrm{CO} 2 \\
\text { on REC }\end{array}$ \\
\hline $\begin{array}{l}\text { Menyah \& } \\
\text { Wolde-Rufael } \\
\text { (2010) }\end{array}$ & 1960-2009 & USA & GC & $\begin{array}{l}\text { No causality from REC } \\
\text { to } \mathrm{CO} 2\end{array}$ \\
\hline $\begin{array}{l}\text { Apergis et al. } \\
(2010)\end{array}$ & 1984 to 2007 & 19 & ECM & REC increases $\mathrm{CO} 2$ \\
\hline Silva et al. (2012) & $1960-2004$ & $\begin{array}{l}\text { USA, Denmark, } \\
\text { Portugal \& Spain }\end{array}$ & SVAR & $\begin{array}{l}\text { Electricity generation has } \\
\text { negative impact by } \mathrm{RE} \\
\text { on } \mathrm{CO} 2 \text { emission }\end{array}$ \\
\hline $\begin{array}{l}\text { Shafiei and Salim } \\
\text { (2014) }\end{array}$ & $1980-2011$ & OECD & PC, AMGE & $\begin{array}{l}\mathrm{REC} \text { reduces } \mathrm{CO} 2 \\
\text { Existence of EKC (CO2 } \\
\text { and urbanization) }\end{array}$ \\
\hline $\begin{array}{l}\text { Apergis \& Payne } \\
(2014)\end{array}$ & 1980-2011 & 25 OECD & $\mathrm{PC}, \mathrm{ECM}$ & $\begin{array}{l}\mathrm{FC} \text { between REC and } \\
\mathrm{CO}_{2}\end{array}$ \\
\hline Zeb et al. (2014) & $1975-2010$ & SAARC & GC & $\begin{array}{l}\text { No causal relation } \\
\text { between } \\
\text { generation by } \mathrm{RE} \text { and } \\
\mathrm{CO}_{2}\end{array}$ \\
\hline $\begin{array}{l}\text { Apergis \& Payne } \\
(2015)\end{array}$ & 1980 to 2010 & 11 & $\mathrm{ECM}, \mathrm{GC}$ & REC enhances $\mathrm{CO} 2$ \\
\hline $\begin{array}{l}\text { Shahbaz et al., } \\
\text { (2015a) }\end{array}$ & $\begin{array}{l}\text { 1972Q1- } \\
\text { 2011Q4 }\end{array}$ & Pakistan & ARDL & $\begin{array}{l}\text { REC increases the } \\
\text { economic growth, REC } \\
\text { casuses growth and vice- } \\
\text { vsresa }\end{array}$ \\
\hline Dogan \& Seker & 1980 to 2012 & EU-15 & DOLS, GC & REC declined CO2 \\
\hline (2016a) & & & & $\begin{array}{l}\text { REC casues } \mathrm{CO} 2 \text { and } \\
\text { vice-versa }\end{array}$ \\
\hline $\begin{array}{l}\text { Dogan \& Seker } \\
(2016 b)\end{array}$ & $1985-2011$ & Top-10 in RE & FMOLS, DOLS & $\begin{array}{l}\text { REC has neagtive impact } \\
\text { on } \mathrm{CO}_{2} \text { emission }\end{array}$ \\
\hline & & & & $\begin{array}{l}\mathrm{REC} \text { casues } \mathrm{CO} 2 \text { and } \\
\text { vice-versa }\end{array}$ \\
\hline $\begin{array}{l}\text { Paramati et al. } \\
\text { (2017) }\end{array}$ & 1990-2012 & 11 & FMOLS, GC & $\begin{array}{l}\text { Negative impact of REC } \\
\text { on } \mathrm{CO}_{2} \text {, }\end{array}$ \\
\hline $\begin{array}{l}\text { Sebri \& Ben- } \\
\text { Salha (2014) }\end{array}$ & 1971-2010 & BRICS & ARDL, VECM & $\begin{array}{l}\mathrm{CO}_{2} \text { emissions boost the } \\
\mathrm{REC}\end{array}$ \\
\hline $\begin{array}{l}\text { Balsalobre- } \\
\text { Lorente et al., } \\
\text { (2018) }\end{array}$ & $1985-2016$ & EU-5 & DOLS & $\begin{array}{l}\text { Natural resource } \\
\text { abundance and RE } \\
\text { reduces } \mathrm{CO}_{2} \text { emissions }\end{array}$ \\
\hline $\begin{array}{l}\text { Sinha \& Shahbaz } \\
\text { (2018) }\end{array}$ & $1971-2015$ & India & ARDL & $\begin{array}{l}\text { REC decrases } \mathrm{CO} 2 \text { in } \\
\text { short-run and long-run }\end{array}$ \\
\hline $\begin{array}{l}\text { Ansari et al. } \\
(2020 \mathrm{c})\end{array}$ & 1991-2017 & GCC & FMOLS, DOLS & $\begin{array}{l}\text { Globalisation increases } \\
\text { environmental polluiton }\end{array}$ \\
\hline
\end{tabular}

464 Note: FMOLS=Fully-Modified-Ordinary-Least-Squares. ARDL=Autoregressive Distributed Lag Model, 465 DOLS=Dynamic Ordinary Least Squares. REC=Renewable Energy Consumption. VECM=Vector Error Correction Mechanism. AMGE: Augmented Mean Group Estimator. PC=Panel Cointegration, ECM=Error Correction model, GC: 
473 Table 2: Survey literature on the link between globalisation, energy consumption, and CO2 emission

\begin{tabular}{|c|c|c|c|c|}
\hline Study & Period & Countries & Method & Results \\
\hline $\begin{array}{l}\text { Shahbaz, et al. } \\
(2018 b)\end{array}$ & $1970-2014$ & Japan & $\begin{array}{l}\text { Asymmetric } \\
\text { threshold version of } \\
\text { the ARDL }\end{array}$ & $\begin{array}{l}\text { Postive link } \\
\text { Globalisation, growth, EC \& } \\
\text { CO2 }\end{array}$ \\
\hline $\begin{array}{l}\text { Shahbaz, et al. } \\
\text { (2018a) }\end{array}$ & $1970-2015$ & BRICS & NARDL & $\begin{array}{l}\text { Positvie link between } \\
\text { globalisation and EC }\end{array}$ \\
\hline $\begin{array}{l}\text { Shahbaz et al. } \\
(2018 \mathrm{~g})\end{array}$ & $\begin{array}{l}\text { 1975Q1- } \\
\text { 2014Q4 }\end{array}$ & UAE & $\begin{array}{l}\text { Cointegration \& } \\
\text { Toda-Yamamoto } \\
\text { causality }\end{array}$ & $\begin{array}{l}\text { Globalisation declined the } \mathrm{CO} 2 \\
\text { emissions }\end{array}$ \\
\hline $\begin{array}{l}\text { Shahbaz, et al. } \\
(2018 \mathrm{c})\end{array}$ & $1970-2014$ & 25 & PC \& AMGE & Globalisation increases the $\mathrm{CO} 2$ \\
\hline $\begin{array}{l}\text { Shahbaz, et al. } \\
(2018 \mathrm{e})\end{array}$ & $\begin{array}{l}\text { 1970Q1- } \\
\text { 2015Q4 }\end{array}$ & Ireland,Netherlands & ARDL (Quantile) & $\begin{array}{l}\text { positive link } \\
\text { globalisation \& EC }\end{array}$ \\
\hline $\begin{array}{l}\text { Shahbaz, et al. } \\
\text { (2016a) }\end{array}$ & $1970-2012$ & China & $\begin{array}{l}\text { Bayer-Hanck } \\
\text { cointegration } \\
\text { \& ARDL }\end{array}$ & $\begin{array}{ll}\text { Ngetaive link } & \text { between } \\
\text { Globalisation } & \mathrm{CO} 2 \text { emissions }\end{array}$ \\
\hline $\begin{array}{l}\text { Shahbaz, et al. } \\
(2016 \mathrm{c})\end{array}$ & $1971-2012$ & 19 African & ARDL & Mix findings \\
\hline $\begin{array}{l}\text { Shahbaz, et al. } \\
(2016 b)\end{array}$ & $1971-2012$ & India & $\begin{array}{l}\text { Bayer-Hanck } \\
\text { cointegration test \& } \\
\text { ARDL }\end{array}$ & globalisation decreases EC \\
\hline Shahbaz, et al. & 1970-2012 & India & Bayer-Hanck & between \\
\hline$(2015 b)$ & & & $\begin{array}{l}\text { cointegration test \& } \\
\text { ARDL }\end{array}$ & $\begin{array}{l}\text { Globalisation, } \\
\text { emissions }\end{array}$ \\
\hline $\begin{array}{l}\text { Ansari, et al } \\
(2020 \mathrm{e})\end{array}$ & 1991-2016 & Top RE & $\begin{array}{l}\text { PMG, FMOLS, \& } \\
\text { DOLS }\end{array}$ & $\begin{array}{l}\text { Negative link between } \\
\text { Globalisation \& } \mathrm{CO} 2 \text { emissions }\end{array}$ \\
\hline
\end{tabular}

474 Note: ARDL=Autoregressive Distributed Lag test. EC=Energy Consumption. REC=renewable energy (RE)

475 consumption. VECM=Vector Error-Correction. AMG=Augmented Mean Group. PMG=Pooled Mean Group.

476

477

478

479

480

481

482

483 
Table 3: Data soucres and description

\begin{tabular}{|c|c|c|c|c|}
\hline Variables & Symbol & Description & Units & Source \\
\hline $\begin{array}{l}\text { Carbon dioxide } \\
\text { emissions }(\mathrm{CO} 2)\end{array}$ & $\mathrm{LnCO}_{2}$ & $\begin{array}{l}\text { Total carbon dioxide emissions from } \\
\text { energy consumption }\end{array}$ & Million metric tons (MMT) & US-EIA \\
\hline Renewable energy & LnREC & $\begin{array}{l}\text { Sum of hydro, modern and traditional } \\
\text { biomass, wind,solar,liquid biofuel, } \\
\text { biogas,geothermal,marine and waste } \\
\text { resource }\end{array}$ & Terajoule (TJ) & SEFA/WB \\
\hline $\begin{array}{l}\text { Non-renewable energy } \\
\text { Carbon dioxide } \\
\text { emissions (CO2) from }\end{array}$ & $\begin{array}{l}\mathrm{LnNREC} \\
\mathrm{LnCO}_{2} \text { coal }\end{array}$ & $\begin{array}{l}\text { Sum of coal, oil and gas consumption } \\
\text { Carbon dioxide emissions from coal } \\
\text { consumption }\end{array}$ & $\begin{array}{l}\text { Quadrillion Btu (Qd. Btu) } \\
\text { MMT }\end{array}$ & $\begin{array}{l}\text { US-EIA } \\
\text { US-EIA }\end{array}$ \\
\hline $\begin{array}{l}\text { Carbon dioxide } \\
\text { emissions (CO2) from } \\
\text { Oil }\end{array}$ & $\mathrm{LnCO}_{2}$ oil & $\begin{array}{l}\text { Carbon dioxide emissions from oil } \\
\text { consumption }\end{array}$ & MMT & US-EIA \\
\hline $\begin{array}{l}\text { Carbon dioxide } \\
\text { emissions }(\mathrm{CO} 2) \text { from } \\
\text { Gas }\end{array}$ & $\mathrm{LnCO}_{2}$ gas & $\begin{array}{l}\text { Carbon dioxide emissions from gas } \\
\text { consumption }\end{array}$ & MMT & US-EIA \\
\hline $\begin{array}{l}\text { Energy consumption } \\
\text { from coal }\end{array}$ & LnEC coal & $\begin{array}{l}\text { Non-renewable energy consumption } \\
\text { particularly from coal }\end{array}$ & $\begin{array}{l}\text { Million tons oil equivalent } \\
\text { (MTOE) }\end{array}$ & $\begin{array}{l}\text { BS-Stats } \\
2018\end{array}$ \\
\hline $\begin{array}{l}\text { Energy consumption } \\
\text { from oil }\end{array}$ & LnEC oil & $\begin{array}{l}\text { Non-renewable energy consumption } \\
\text { particularly from oil }\end{array}$ & MTOE & $\begin{array}{l}\text { BS-Stats } \\
2018\end{array}$ \\
\hline $\begin{array}{l}\text { Energy consumption } \\
\text { from gas }\end{array}$ & LnEC gas & $\begin{array}{l}\text { Non-renewable energy consumption } \\
\text { particularly from gas }\end{array}$ & MTOE & $\begin{array}{l}\text { BS-Stats } \\
2018\end{array}$ \\
\hline Total factor productivity & LnTFP & measured as constant prices $(2011=1)$ & Constant prices 2011 & PWT \\
\hline Globalisation index & LnG & $\begin{array}{l}\text { measured by (Dreher, 2006) as KOF } \\
\text { index of globalisation consist of } \\
\text { mainly three parameters ( economic, } \\
\text { political and social) }\end{array}$ & index & $\begin{array}{l}\text { ETH } \\
\text { Zurich }\end{array}$ \\
\hline
\end{tabular}

$487 \quad$ Note: US-EIA=United States Energy Information Agrancy. SEFA/WB=Sustainable Energy for All published by World

488 Bank. BS=Stats Brisitsh Petrolium Statistics. PWT= Penn World Table. ETH=Ethereum Zurich 
Table 4: Cross sectional dependence results

\begin{tabular}{|c|c|c|c|c|c|c|c|c|c|c|c|}
\hline Variables & $\mathrm{LnCO}_{2}$ & $\begin{array}{l}\mathrm{LnCO}_{2} \\
\text { coal }\end{array}$ & $\begin{array}{l}\mathrm{LnCO}_{2} \\
\text { oil }\end{array}$ & $\begin{array}{l}\mathrm{LnCO}_{2} \\
\text { gas }\end{array}$ & $\begin{array}{l}\text { LnEC } \\
\text { coal }\end{array}$ & $\begin{array}{l}\text { LnEC } \\
\text { oil }\end{array}$ & $\begin{array}{l}\text { LnEC } \\
\text { gas }\end{array}$ & $\begin{array}{l}\text { LnNRE } \\
\text { C }\end{array}$ & LnREC & LnTFP & LnG \\
\hline \multirow{2}{*}{$\begin{array}{l}\text { Breusch- } \\
\text { Pagan LM } \\
\text { Prob. }\end{array}$} & $982.77 *$ & $\begin{array}{l}958.19 \\
*\end{array}$ & $\begin{array}{l}713.55 \\
*\end{array}$ & $\begin{array}{l}888.01 \\
*\end{array}$ & $978.69 *$ & 931.17* & $981.19 *$ & $\begin{array}{l}1093.90 \\
*\end{array}$ & $356.74 *$ & $327.45^{*}$ & $1072.65^{*}$ \\
\hline & 0.00 & 0.00 & 0.00 & 0.00 & 0.00 & 0.00 & 0.00 & 0.00 & 0.00 & 0.00 & 0.00 \\
\hline $\begin{array}{l}\text { Pesaran } \\
\text { CD }\end{array}$ & $31.251 *$ & $30.58 *$ & $25.08 *$ & $29.31 *$ & $31.21 *$ & $30.36 *$ & $31.18 *$ & $33.06 *$ & $9.32 *$ & $4.81 *$ & $32.73 *$ \\
\hline Prob. & 0.00 & 0.00 & 0.00 & 0.00 & 0.00 & 0.00 & 0.00 & 0.00 & 0.00 & 0.00 & 0.00 \\
\hline $\begin{array}{l}\text { Pesaran } \\
\text { scaled LM }\end{array}$ & $98.84 *$ & $96.25^{*}$ & $70.47 *$ & $88.86^{*}$ & $98.42 *$ & $93.41 *$ & $98.68 *$ & $110.56^{*}$ & $32.86^{*}$ & $29.77 *$ & $108.32 *$ \\
\hline Prob. & 0.00 & 0.00 & 0.00 & 0.00 & 0.00 & 0.00 & 0.00 & 0.00 & 0.00 & 0.00 & 0.00 \\
\hline $\begin{array}{l}\text { Bias- } \\
\text { corrected } \\
\text { scaled LM }\end{array}$ & $98.64 *$ & $96.05^{*}$ & $70.27^{*}$ & $88.66^{*}$ & $98.22 *$ & $93.21 *$ & $98.48^{*}$ & $110.36^{*}$ & $32.66^{*}$ & $29.57 *$ & $108.12 *$ \\
\hline Prob. & 0.00 & 0.00 & 0.00 & 0.00 & 0.00 & 0.00 & 0.00 & 0.00 & 0.00 & 0.00 & 0.00 \\
\hline
\end{tabular}

506

507

508

509

510

Note: *Cross sectional independence is rejected at 1 percent level of significance, LM \& CD test performs the null hypothesis of cross sectional independence.

Table 5: Results of Panel unit root test

\begin{tabular}{|c|c|c|c|c|c|c|c|c|}
\hline Variables & $\begin{array}{l}\text { IPS unit } \\
\text { root test }\end{array}$ & & $\begin{array}{l}\text { ADF } \\
\text { unit } \\
\text { root test }\end{array}$ & & $\begin{array}{l}\text { PP Unit } \\
\text { root }\end{array}$ & & $\begin{array}{l}\text { LLC } \\
\text { unit root }\end{array}$ & \\
\hline & Level & $\begin{array}{l}\text { First } \\
\text { difference }\end{array}$ & Level & $\begin{array}{l}\text { First } \\
\text { difference }\end{array}$ & Level & $\begin{array}{l}\text { First } \\
\text { difference }\end{array}$ & Level & $\begin{array}{l}\text { First } \\
\text { difference }\end{array}$ \\
\hline $\mathrm{LnCO}_{2}$ & 3.87 & $-11.08 * * *$ & 6.80 & $137.78 *$ & 9.68 & $143.83^{*}$ & -0.65 & $-12.59^{*}$ \\
\hline $\mathrm{LnCO}_{2} \mathrm{coal}$ & 3.15 & $-10.42 * * *$ & 10.30 & $130.92 *$ & 1.44 & $146.98 *$ & 2.91 & $-13.06^{*}$ \\
\hline $\mathrm{LnCO}_{2} \mathrm{oil}$ & 1.19 & $-11.33^{*}$ & 17.33 & $139.34 *$ & 17.15 & $131.44 *$ & -1.24 & $-11.92 *$ \\
\hline $\mathrm{LnCO}_{2}$ gas & $-2.30 * *$ & $-7.05^{*}$ & $45.05^{*}$ & $86.96^{*}$ & $78.67 *$ & $95.67 *$ & $-5.38^{*}$ & $-7.14^{*}$ \\
\hline LnEC coal & 2.00 & $-10.66^{*}$ & 10.48 & $133.78^{*}$ & 16.08 & $146.41^{*}$ & -0.45 & $-10.33^{*}$ \\
\hline LnEC oil & $-1.96 * *$ & $-10.04 *$ & $37.38 * *$ & $124.31 *$ & $53.65^{*}$ & $123.64 *$ & $-4.02 *$ & $-11.63 *$ \\
\hline LnEC gas & $-2.12 * *$ & $-7.94 *$ & $44.71^{*}$ & $96.14^{*}$ & $57.99 *$ & $95.77 *$ & $-6.15^{*}$ & $-7.86^{*}$ \\
\hline LnNREC & -0.81 & $-9.61 *$ & $33.53^{* *}$ & $120.96 *$ & $46.80 *$ & $135.30 *$ & $-3.10^{*}$ & $-8.70^{*}$ \\
\hline LnREC & 2.71 & $-7.11 *$ & 15.28 & $90.09 *$ & 11.87 & $95.82^{*}$ & 2.99 & $-6.97 *$ \\
\hline LnTFP & 2.21 & $-10.26^{*}$ & 10.11 & $126.55^{*}$ & 10.16 & $131.41 *$ & 0.83 & $-10.18^{*}$ \\
\hline LnG & $-6.27 *$ & $-9.59 *$ & $79.84 *$ & $118.07 *$ & $94.91 *$ & $120.10^{*}$ & $-9.86^{*}$ & $-10.97 *$ \\
\hline
\end{tabular}

511 Note: $* * * \& * * *$ denote the null of non-stationary is rejected against the alternative null of stationary at $1,5 \& 10$ 512 percent level of significance. 
524 Table 6: Results of Panel cointegration test

\begin{tabular}{|c|c|c|c|c|c|c|c|c|}
\hline a: Pedroni & Model 1 & & Model 2 & & Model 3 & & Model 4 & \\
\hline & $\begin{array}{l}\text { Non- } \\
\text { renewable } \\
\text { Energy }\end{array}$ & & $\begin{array}{l}\text { Coal } \\
\text { consumption }\end{array}$ & & $\begin{array}{l}\text { Oil } \\
\text { consumption }\end{array}$ & & $\begin{array}{l}\text { Gas } \\
\text { consumption }\end{array}$ & \\
\hline \multicolumn{9}{|c|}{ Within-dimension } \\
\hline & Statistic & Prob. & Statistic & Prob. & Statistic & Prob. & Statistic & Prob. \\
\hline $\begin{array}{l}\text { Panel v } \\
\text { Statistic }\end{array}$ & 0.46 & 0.32 & 0.65 & 0.25 & -0.75 & 0.77 & -0.24 & 0.59 \\
\hline $\begin{array}{l}\text { Panel rho } \\
\text { Statistic }\end{array}$ & 1.46 & 0.92 & 1.43 & 0.92 & 1.42 & 0.92 & 1.96 & 0.97 \\
\hline $\begin{array}{l}\text { Panel PP- } \\
\text { Stats }\end{array}$ & -3.01 & $0.001 *$ & -5.13 & $0.00 *$ & -2.51 & $0.00 *$ & -1.57 & $0.05 * * *$ \\
\hline $\begin{array}{l}\text { Panel ADF } \\
\text { Stats }\end{array}$ & -3.95 & $0.00 *$ & -2.42 & $0.00 *$ & -2.38 & $0.00 *$ & -1.35 & $0.08 * * *$ \\
\hline \multicolumn{9}{|c|}{ Between-dimension } \\
\hline & Statistic & Prob. & Statistic & Prob. & Statistic & Prob. & Statistic & Prob. \\
\hline $\begin{array}{l}\text { Group rho } \\
\text { Stats }\end{array}$ & 2.37 & 0.99 & 2.77 & 0.99 & 2.47 & 0.99 & 3.22 & 0.99 \\
\hline $\begin{array}{l}\text { Group PP } \\
\text { Stats }\end{array}$ & -3.05 & $0.00^{*}$ & -3.81 & $0.00 *$ & -10.08 & $0.00 *$ & -7.51 & $0.00 *$ \\
\hline $\begin{array}{l}\text { Group ADF } \\
\text { Stats }\end{array}$ & -3.02 & $0.00 *$ & -2.22 & $0.01 * *$ & -6.09 & $0.00 *$ & -3.76 & $0.00 *$ \\
\hline \multicolumn{9}{|l|}{ b: Kao test } \\
\hline & t-Statistic & Prob. & t-Statistic & Prob. & t-Statistic & Prob. & t-Statistic & Prob. \\
\hline & -1.95 & $0.02 * *$ & -3.49 & $0.00 *$ & -4.83 & $0.00 *$ & -8.57 & $0.00 *$ \\
\hline
\end{tabular}

Note: $*$ and $* *$ indicates the rejection of null hypothesis of no cointegration at 1 and 5 percent level of

526 significance

527

528

529

530

531

532

533

534

535

536

537

538

539

540 
Table 7: Results of long-run and short-run elasticity

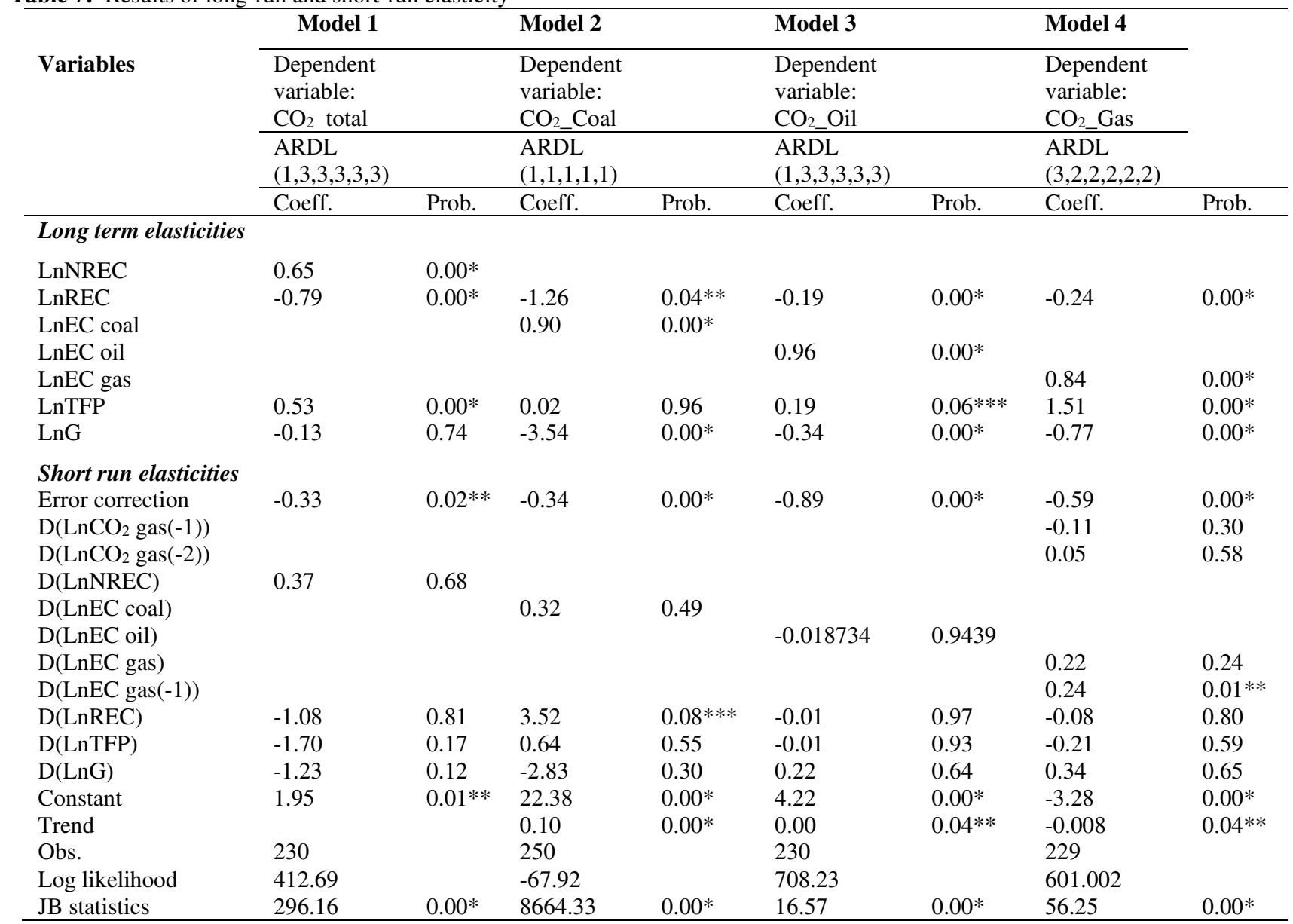


Table 8: Results of Dumiterescu-Hurlin panel granger causality test

\begin{tabular}{|c|c|c|c|}
\hline & Null Hypothesis & Statisitics & Prob. \\
\hline \multirow{8}{*}{ Model 1} & $\mathrm{LnNREC} \nRightarrow \mathrm{LnCO}_{2}$ & 2.71 & $0.00 *$ \\
\hline & $\mathrm{LnCO}_{2} \nRightarrow \mathrm{LnNREC}$ & 1.09 & 0.98 \\
\hline & $\mathrm{LnREC} \nRightarrow \mathrm{LnCO}_{2}$ & 2.74 & $0.00 *$ \\
\hline & $\mathrm{LnCO}_{2} \nRightarrow \mathrm{LnREC}$ & 3.76 & 5.07 \\
\hline & $\mathrm{LnG} \nRightarrow \mathrm{LnCO}_{2}$ & 1.00 & 0.86 \\
\hline & $\mathrm{LnCO}_{2} \nRightarrow \mathrm{LnG}$ & 1.63 & 0.31 \\
\hline & $\mathrm{LnTFP} \nRightarrow \mathrm{LnCO}_{2}$ & 1.62 & $0.09 * * *$ \\
\hline & $\mathrm{LnCO}_{2} \nRightarrow \mathrm{LnTFP}$ & 2.39 & $0.01 * *$ \\
\hline \multirow{8}{*}{ Model 2} & LnEC coal $\nRightarrow \mathrm{LnCO}_{2}$ coal & 2.44 & $0.01 * *$ \\
\hline & $\mathrm{LnCO}_{2} \mathrm{coal} \nRightarrow \mathrm{LnEC}$ coal & 1.38 & 0.58 \\
\hline & $\mathrm{LnREC} \nRightarrow \mathrm{LnCO}_{2} \mathrm{coal}$ & 2.45 & $0.01 * *$ \\
\hline & $\mathrm{LnCO}_{2}$ coal $\nRightarrow$ LnREC & 4.66 & 2.00 \\
\hline & $\mathrm{LnG} \nRightarrow \mathrm{LnCO}_{2}$ coal & 1.84 & 0.16 \\
\hline & $\mathrm{LnCO}_{2} \mathrm{coal} \nRightarrow \mathrm{LnG}$ & 1.08 & 0.97 \\
\hline & LnTFP $\nRightarrow \mathrm{LnCO}_{2}$ coal & 2.00 & $0.08^{* * * *}$ \\
\hline & $\mathrm{LnCO}_{2} \mathrm{coal} \nRightarrow \mathrm{LnTFP}$ & 2.90 & $0.00 *$ \\
\hline \multirow{8}{*}{ Model 3} & LnEC oil $\nRightarrow \mathrm{LnCO}_{2}$ oil & 3.69 & $0.06^{* * * *}$ \\
\hline & $\mathrm{LnCO}_{2}$ oil $\nRightarrow$ LnEC oil & 3.45 & 0.12 \\
\hline & LnREC $\nRightarrow \mathrm{LnCO}_{2} \mathrm{oil}$ & 4.79 & $0.00 *$ \\
\hline & $\mathrm{LnCO}_{2} \mathrm{Oil} \nRightarrow \mathrm{LnREC}$ & 5.61 & 2.00 \\
\hline & $\mathrm{LnG} \nRightarrow \mathrm{LnCO}_{2} \mathrm{oil}$ & 1.53 & 0.37 \\
\hline & $\mathrm{LnCO}_{2} \mathrm{oil} \nRightarrow \mathrm{LnG}$ & 2.47 & 0.76 \\
\hline & $\mathrm{LnTFP} \nRightarrow \mathrm{LnCO}_{2} \mathrm{Oil}$ & 2.26 & 0.96 \\
\hline & $\mathrm{LnCO}_{2} \mathrm{oil} \nRightarrow$ LnTFP & 4.68 & $0.00 *$ \\
\hline \multirow{8}{*}{ Model 4} & $\mathrm{LnEC}$ gas $\nRightarrow \mathrm{LnCO}_{2}$ gas & 1.88 & 0.13 \\
\hline & $\mathrm{LnCO}_{2}$ gas $\nRightarrow \mathrm{LnEC}$ gas & 2.42 & $0.01 * *$ \\
\hline & $\mathrm{LnREC} \nRightarrow \mathrm{LnCO}_{2}$ gas & 1.41 & 0.55 \\
\hline & $\mathrm{LnCO}_{2}$ gas $\nRightarrow$ LnREC & 2.80 & $0.00^{*}$ \\
\hline & LnG does $\nRightarrow \mathrm{LnCO}_{2}$ gas & 3.50 & 6.00 \\
\hline & $\mathrm{LnCO}_{2} \mathrm{gas} \nRightarrow \mathrm{LnG}$ & 2.28 & $0.02 * *$ \\
\hline & LnTFP does $\nRightarrow \mathrm{LnCO}_{2}$ gas & 1.79 & 0.19 \\
\hline & $\mathrm{LnCO}_{2}$ gas $\nRightarrow \mathrm{LnTFP}$ & 2.58 & $0.00^{*}$ \\
\hline
\end{tabular}

567 Note: $* * *$, and $* * *$ indicates rejecting of null hypothesis at 1,5 and 10 percent level of significance. $\nRightarrow$ 568 indicates does not cause. 